\title{
META-ANALISIS MODEL PEMBELAJARAN PROBLEM BASED LEARNING (PBL) PADA PEMBELAJARAN FISIKA
}

\author{
Suhardiman, Epi Purnama, Ummul Hasanah, Yusuf Hidayat, Hasbullahair Azhar
}

Pendidikan Fisika, Fakultas Tarbiyah dan Keguruan, UIN Alauddin Makassar, suhardiman.hardi@uin-alauddin.ac.id

\begin{abstract}
Abstrak
Tujuan penelitian ini adalah untuk mengetahui besar pengaruh model pembelajaran Problem Based Learning (PBL) terhadap pembelajaran Fisika secara keseluruhan, berdasarkan jenjang pendidikan, variabel terikat penelitian dan materi pelajaran. Jenis penelitian ini adalah penelitian Meta-analisis. Subjek penelitian ini berupa artikel ilmiah yang telah dipublikasi oleh beberapa jurnal di Indonesia tentang penggunaan model pembelajaran Problem Based Learning (PBL) tahun 2011-2020 pada konsep materi Fisika dengan kriteria yang telah ditentukan. Instrumen penelitian yang digunakan adalah lembar pemberian kode (coding). Effect size yang diperoleh untuk jenjang SLTP 0,355 (kategori besar) dan SLTA 0,244 (kategori sedang). Besar pengaruh model Problem Based Learning (PBL) pada pembelajaran Fisika berdasarkan variabel terikat memiliki effect size pada kemampuan berpikir kritis, kemampuan berpikir kreatif, literasi sains dan prestasi belajar berada pada kategori besar, sedangkan hasil belajar, kemampuan pemahaman konsep dan kemampuan pemecahan masalah berada pada kategori sedang. Besar pengaruh model Problem Based Learning (PBL) pada pembelajaran Fisika berdasarkan materi atau pokok bahasan memiliki effect size pada materi Hukum Newton dan Cahaya dan Optik berada pada kategori besar, sedangkan Fluida Statis, Suhu dan Kalor, dan Listrik Dinamis berada pada kategori sedang.
\end{abstract}

Kata kunci: Meta-analisis; Effect size; Problem Based Learning; Pembelajaran Fisika

\section{PENDAHULUAN}

Perkembangan dalam dunia pendidikan saat ini telah meningkat dengan pesat seiring bekembangan teknologi informasi dan komunikasi. Dari dalam kurikulum 13 pmerintah berupaya memperbaiki kualitas pendidikan di Indonesia menjadi lebih baik (Ginaya, Kanca, \& Sri Astuti, 2020). Hal yang mencolok dalam kurikulum 2013 pembelajaran saintifik dan pembelajaran aktif yaitu pembelajaran yang berpusat pada peserta didik (student center learning). Peserta didik memiliki peran yang lebih banyak dalam menemukan konsep atau pengetahuan baru (Pratiwi, 2019). Salah satu model pembelajaran ilmiah yang dapat digunakan yaitu model Problem Based Learning (PBL).

Model Problem Based Learning (PBL) bercirikan penggunaan masalah kehidupan nyata sebagai sesuatu yang harus dipelajari oleh peserta didik untuk melatih dan meningkatkan keterampilan berpikir kritis sekaligus pemecahan masalah, serta memperoleh pengetahuan tentang konsep-konsep penting (Rahmat, Pasaribu, \& Darmadi, 2016). Masalah yang disajikan dalam pembelajaran berbasis masalah menuntut peserta didik untuk aktif memecahkan masalah melalui metode ilmiah, sehingga peserta didik memiliki peran lebih dalam proses pembelajaran (Manalu, 2016). Melalui model pembelajaran ini peserta didik dilatih untuk peka terhadap permasalahan yang terdapat di lingkungannya dan mampu memberikan argumen yang bersifat solutif terhadap permasalahan tersebut (Hidayah, Pujani, \& Sujanem, 2018). Aktivitas dalam pembelajaran menggunakan model Problem Based Learning (PBL) mampu meransang rasa ingin tahu peserta didik sehingga memberi motivasi untuk meningkatkan ketertarikannya terhadap isu-isu ilmiah yang memungkinkan untuk diselidiki melalui langkah-langkah, metode ilmiah dan meningkatkan rasa tanggung jawab peserta didik terhadap lingkungan sekitarnya dengan penerapan konsep-konsep sains yang telah dipelajari(Jiniarti, Sahidu, \& Verawati, 2017). Fokus pembelajaran pada model Problem Based Learning (PBL) adalah masalah yang disajikan (Deswita, 2018). Melalui model ini peserta didik tidak hanya mempelajari konsep-konsep yang berhubungan dengan masalah tetapi juga metode ilmiah untuk memahami konsep yang relevan dengan masalah yang menjadi topik pembelajaran. 
Selama ini model Problem Based Learning (PBL) sudah banyak terapakan dalam pembelajran fisika (Phasa, 2020). Bentuk penerapanya cukup beragam bergantung pada jenis variabel dan fokus penelitiannya. Problem Based Learning sangat sesuai jika diterapkan dalam pembelajaran fisika (Ariani \& Suanti, 2016). Hal ini dikarenakan karakteristik materi fisika yang landasan berpikirnya dibangun berdasarkan fenomena alam melalui penyelidikan ilmiah (Demirel \& Dağyar, 2016). Namun agar dapat mengetahui secara lebih spesifik pengaruh dari model Problem Based Learning terhadap pembelajaran fisika maka perlu diadakan telaah berupa analisis dokumen hasil penelitian yang tekah diterbitkan dari berbagai jurnal ilmiah yang kredibel. Analisis ini kemudian dinamkan meta analisis. Analisis meta (metaanalysis) merupakan penelitian yang menggunakan studi-studi yang telah ada dan telah digunakan oleh peneliti yang dilakukan secara sistematis dan kuantitatif untuk memperoleh kesimpulan yang akurat (Retnawati, Apino, Kartianom, Djidu, \& Anazifa, 2018). Kelebihan dari meta analisis yaitu dapat mengetahui secara spesifik besar dampak atau pengaruh Problem Based Learning pada setiap variable, jejang Pendidikan bahkan spesifikasi materi fisika yang sesuai dengan model Problem Based Learning. Maka dari itu penelitian ini bertujuan untuk mengatahui mengetahui besar pengaruh model pembelajaran Problem Based Learning (PBL) terhadap pembelajaran Fisika secara keseluruhan, berdasarkan jenjang pendidikan, variabel terikat penelitian dan materi pelajaran.

\section{METODE PENELITIAN}

Metode penelitian yang digunakan adalah penelitian deskriptif dengan pendekatan pengumpulan data Meta-Analysis. Subjek penelitian ini adalah artikel ilmiah yang telah dipublikasi oleh beberapa jurnal berskala nasional di Indonesia tentang penggunaan model pembelajaran Problem Based Learning (PBL) tahun 2010-2020 pada konsep materi Fisika dengan kriteria jenis penelitian yaitu: (1) artikel ditulis oleh peneliti umum atau mahasiswa, (2) artikel menggunakan metode penelitian eksperimen, (3) merupakan artikel tingkat nasional berasal dari jurnal yang telah terakreditasi oleh Kementrian Riset Teknologi dan Pendidikan Tinggi Republik Indonesia (RISTEKDIKTI) di Sinta Indonesia dan telah terindeks pada http://sinta.ristekdikti.go.id/,(4) artikel merupakan penelitian kuantitatif dan memenuhi data statistik effect size, (5) artikel diterbitkan 10 tahun terakhir yaitu 2010-2020, (6) artikel bertema pembelajaran Problem Based Learning (PBL) pada konsep materi Fisika, (7) sampel jenjang pendidikan pada artikel merupakan pada jenjang Sekolah Menengah Pertama (SMP) dan Sekolah Menengah Atas (SMA); dan (8) cakupan wilayah penelitian artikel dilakukan di kawasan Indonesia.

Instumen yang digunakan dalam penelitian ini adalah lembar pemberian kode (coding data). Variabel-variabel dalam coding data yaitu: (a) nama peneliti, (b) Tahun penelitian, (c) subjek penelitian, (d) variabel penelitian, (e) desain penelitian, (f) ukuran sampel. Teknik analisis data menggunakan analisis deskriptif kuantitatif dengan melihat effect size. Penentuan effect size untuk mewakili hasil temuan kuantitatif dari beberapa penelitian dalam bentuk standar yang memungkinkan perbandingan numerik dan analisis bermakna pada keseluruhan penelitian (Retnawati dkk, 2018: 20). Menghitung effect size masing-masing artikel penelitian dapat ditentukan dengan berbagi formula atau rumus. Formula effect size yang hanya melibatkan dua kelompok, yaitu kelompok eksperimen dan kelompok kontrol, menggunakan analisis komparasi dengan teknik analisis uji-t. Maka menggunakan formula effect size sebagai berikut:

$$
\eta^{2}=\mathrm{r}^{2}=\frac{t_{0}{ }^{2}}{t_{0}{ }^{2}+d b}
$$

Ket: $\quad \eta^{2}=\mathrm{r}^{2}=$ effect Size

$$
\begin{aligned}
& \mathrm{t} 0=\mathrm{t} \text { hitung } \\
& \mathrm{db}=\text { derajat bebas }
\end{aligned}
$$

Untuk penelitian eksperimen melibatkan lebih dari dua kelompok, menggunakan analisis komparasi dengan teknik analisis Anova satu jalur. Menentukan besar pengaruh variabel bebas terhadap variabel terikat dapat dihitung dengan dengan menggunakan koefisien determinasi:

$$
\eta^{2}=\mathrm{r}^{2}=\frac{I K(A)}{J K(B)}
$$


Untuk penelitian yang melibatkan lebih dari dua kelompok dan interaksinya maka digunakan analisis komparasi dengan teknik analisis Anova2 jalan, maka dapat diformulasikan sebagai berikut:

$$
\begin{aligned}
& \eta_{A}{ }^{2}=\frac{J K(A)}{J K(A)+J K(D)} \\
& \eta_{B}{ }^{2}=\frac{J K(B)}{J K(B)+J K(D)} \\
& \eta_{A B^{2}}=\frac{J K(A B)}{J K(A B)+J K(D)}
\end{aligned}
$$

Keterangan:

$$
\begin{array}{ll}
\eta_{A}{ }^{2} & =\text { Eta Squard A } \\
\eta_{B}{ }^{2} & =\text { Eta Squard B } \\
\eta_{A}{ }^{2} & =\text { Eta Squard AB (Kadir, 2016: } \\
318) & \\
\mathrm{JK}(\mathrm{A}) & =\text { Jumlah Kuadrat Jalur A } \\
\mathrm{JK}(\mathrm{B}) & =\text { Jumlah Kuadrat Jalur B } \\
\mathrm{JK}(\mathrm{D}) & =\text { Jumlah Kuadrat } \\
\mathrm{JK}(\mathrm{AB}) & =\text { Jumlah Kuadrat AB }
\end{array}
$$

(Kadir, 2015)
Penelitian eksperimen berdasarkan kelompok heterogen dua kelompok, maka diformulasikan sebagai berikut:

$$
\Delta=\frac{\bar{x}_{\varepsilon}-\bar{x}_{K}}{s_{K}}
$$

Kriteria yang digunakan untuk interpretasi hasil effect size menggunakan acuan Gravetter dan Wallnau, yaitu:

Efek kecil $\quad: 0.01<\eta^{2} \leq 0.09$

Efek sedang $: 0.09<\eta^{2} \leq 0.25$

Efek besar $: \eta^{2}>0.25$

(Kadir, 2017)

\section{HASIL DAN PEMBAHASAN}

\section{Kriteria Effect Size Setiap Atrikel}

Data dari artikel ilmiah dalam bentuk effect size dikategorikan dalam tiga kriteria yaitu efek kecil $\left(0.01<\eta^{2} \leq 0.09\right)$, efek sedang $\left(0.09<\eta^{2} \leq\right.$ $0.25)$, efek besar $\left(\eta^{2}>0.2\right)$. Besar pengaruh model Problem Based Learning (PBL) pada pembelajaran Fisika berdasarkan kategori dapat dilihat pada tabel berikut:

Tabel 1. Effect Size Berdasarkan Kategori

\begin{tabular}{lrrrrc}
\hline Study & $\begin{array}{c}\text { Jumlah sub } \\
\text { efek }\end{array}$ & Effect Size & $\begin{array}{c}\text { Rata-Rata } \\
\text { Effect size }\end{array}$ & Kategori & N artikel \\
\hline A47 & 1 & 0.044 & 0.044 & Kecil & 4 \\
A52 & 1 & 0.049 & 0.049 & & \\
A41 & 1 & 0.059 & 0.059 & & \\
A57 & 1 & 0.087 & 0.087 & & 19 \\
A53 & 1 & 0.095 & 0.095 & Sedang & \\
A42 & 1 & 0.104 & 0.104 & & \\
A22 & 1 & 0.116 & 0.116 & & \\
A51 & 1 & 0.12 & 0.12 & & \\
A46 & 1 & 0.125 & 0.125 & & \\
A59 & 1 & 0.126 & 0.126 & & \\
A19 & 1 & 0.14 & 0.14 & Besar & \\
A48 & 1 & 0.144 & 0.144 & & \\
A27 & 1 & 0.151 & 0.151 & & \\
A58 & 1 & 0.16 & 0.16 & & \\
A54 & 1 & 0.168 & 0.168 & & \\
A43 & 1 & 0.191 & 0.191 & \\
\hline
\end{tabular}




\begin{tabular}{|c|c|c|c|c|c|}
\hline Study & $\begin{array}{c}\text { Jumlah sub } \\
\text { efek }\end{array}$ & Effect Size & $\begin{array}{l}\text { Rata-Rata } \\
\text { Effect size }\end{array}$ & Kategori & $\mathrm{N}$ artikel \\
\hline A23 & 1 & 0.193 & 0.193 & & \\
\hline A12 & 1 & 0.197 & 0.197 & & \\
\hline A 37 & 1 & 0.226 & 0.226 & & \\
\hline A24 & 1 & 0.231 & 0.231 & & \\
\hline A 10 & 1 & 0.237 & 0.237 & & \\
\hline A 13 & 1 & 0.24 & 0.24 & & \\
\hline A11 & 1 & 0.284 & 0.284 & & \\
\hline A40 & 1 & 0.36 & 0.36 & & \\
\hline A50 & 2 & 0.41 & 0.353 & & \\
\hline A20 & 1 & $\begin{array}{l}0.608 \\
0.536\end{array}$ & 0.536 & & \\
\hline $\mathrm{A} 2$ & 1 & 0.619 & 0.619 & & \\
\hline A55 & 1 & 0.626 & 0.626 & & \\
\hline A17 & 1 & 0.787 & 0.787 & & \\
\hline A26 & 1 & 0.81 & 0.81 & & \\
\hline A45 & 1 & 0.893 & 0.893 & & \\
\hline Rata-rata & & 0.285 & & Efek Besar & \\
\hline Jumlah & 32 & & & & 31 \\
\hline
\end{tabular}

Hasil analisis data pada Tabel 1 menunjukkan bahwa effect size pada model pembelajaran Problem Based Learning (PBL) bervariasi, empat artikel memiliki effect size yang kecil, sembilan belas artikel memiliki effect sedang dan 8 artikel menunjukkan effect size besar.

Tabel 2. Effect Size Secara Keseluruhan

\begin{tabular}{lcccccccc}
\hline M & V & SEM & LLM & ULM & P-Value & R & LLr & UULr \\
\hline 0.585 & 0.0005 & 0.023 & 0.539 & 0.631 & 0 & 0.526 & 0.492 & 0.559 \\
\hline
\end{tabular}

(Effect Size) disajikan dalam tabel berikut:

Dari hasil perhitungan effect size diperoleh $\mathrm{r}^{2}$ sebesar 0,285 termasuk dalam kategori besar, sehingga disimpulkan bahwa terdapat hubungan yang signifikan model PBL pada pembelajaran fisika.hal itu dibuktikan dengan nilai $p$-value $<0,05$ dan interval kepercayaan berada pada rentang $0,492-0,559$.

\section{Pengaruh Model Pembelajaran Problem Based Learning (PBL) Terhadap Pembelajaran Fisika berdasarkan Jenjang Pendidikan}

Jenjang pendidikan yang dianalisis dalam penelitian ini adalah SLTP sederajat dan SLTA
Tabel 3. Effect Size berdasarkan Jenjang Pendidikan

\begin{tabular}{cllllll}
\hline $\begin{array}{c}\text { Jenjang } \\
\text { Pendidikan }\end{array}$ & $\mathbf{N}$ & $\mathbf{r}^{2}$ & $\mathbf{R}$ & $\mathbf{S E}$ & $\mathbf{L L r}$ & $\mathbf{U L r}$ \\
\hline SLTP & 12 & 0.355 & 0.596 & 0.04 & 0.543 & 0.644 \\
SLTA & 19 & 0.244 & 0.494 & 0.03 & 0.449 & 0.537 \\
\hline
\end{tabular}

Dari data yang terangkum pada Tabel 3 dapat dilihat bahwa effect size pembelajaran Problem Based Learning (PBL) pada mata pelajaran Fisika untuk jenjang pendidikan SLTP diperoleh $\mathrm{r}^{2}=$ 0.355 (efek besar) dan SLTA diperoleh $\mathrm{r}^{2}=0.244$ (efek sedang) sehingga dapat disimpulkan bahwa model PBL memiliki pengaruh yang besar terhadap pembelajaran fisika baik di jenjang SLTP maupun SLTA. Model pembelajaran PBL 
terdapat hubungan yang signifikan model PBL pada pembelajaran fisika, hal itu dibuktikan dengan nilai $p$-value $<0,05$ dan interval kepercayaan berada pada rentang 0,543-0,644 untuk jenjang SLTP dan 0,449-0,537 untuk jenjang SLTA.

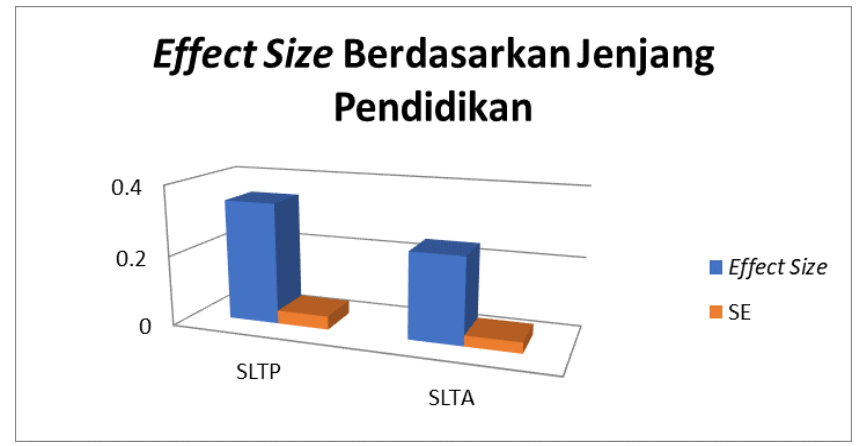

Gambar 1. Effect size berdasarkan Jenjang Pendidikan
Berdasarkan gambar 1 menunjukkan bahwa ratarata effect size pada kedua jenjang termasuk dalam kategori besar. Jenjang pendidikan SLTP memiliki effect size yang lebih tinggi pada pembelajaran fisika meskipun memiliki efek yang cukup bervariasi, namun kita dapat mengatakan bahwa jenjang ini yang sangat efektif untuk diterapkan model PBL.

\section{Pengaruh Model Pembelajaran Problem Based Learning (PBL) Terhadap Pembelajaran Fisika berdasarkan Variabel Terikat}

Data hasil analisis besar pengaruh (effect size) berdasarkan variabel terikat penelitian disajikan dalam Tabel berikut:

Tabel 4. Effect size berdasarkan variabel terikat

\begin{tabular}{ccccccc}
\hline Variabel Terikat & $\mathbf{N}$ & $\mathbf{r}^{2}$ & $\mathbf{R}$ & $\mathbf{S E}$ & $\mathbf{L L r}$ & ULr \\
\hline Hasil Belajar & 15 & 0.188 & 0.433 & 0.036 & 0.374 & 0.489 \\
Keterampilan Berpikir Kritis & 4 & 0.350 & 0.592 & 0.064 & 0.504 & 0.668 \\
kemampuan Pemahaman Konsep & 2 & 0.124 & 0.352 & 0.101 & 0.169 & 0.512 \\
Kemampuan Pemecahan Masalah & 3 & 0.173 & 0.415 & 0.076 & 0.284 & 0.532 \\
Kemampuan Berpikir Kreatif & 2 & 0.575 & 0.758 & 0.089 & 0.674 & 0.823 \\
Literasi Sains & 2 & 0.477 & 0.691 & 0.11 & 0.560 & 0.788 \\
Prestasi Belajar & 2 & 0.552 & 0.743 & 0.11 & 0.630 & 0.825 \\
\hline
\end{tabular}

Dari data yang terangkum pada Tabel 4 dapat dilihat bahwa Effect Size (ES) pembelajaran Problem Based Learning (PBL) pada mata pelajaran Fisika terhadap hasil belajar diperoleh $\mathrm{r}^{2}=0.188$ (efek sedang), sehingga dapat disimpulkan bahwa model Problem Based Learning (PBL) memiliki pengaruh yang signifikan terhadap hasil belajar peserta didik yang dapat dilihat dari nilai $p$-value $0.000<0,05$ dan interval kepercayaan berada pada rentang $0,374-0,489$.

\section{Effect size pembelajaran Problem Based} Learning (PBL) pada mata pelajaran Fisika terhadap keterampilan berpikir kritis diperoleh $\mathrm{r}^{2}$ $=0.35$ (efek besar), sehingga dapat disimpulkan bahwa model Problem Based Learning (PBL) memiliki pengaruh yang signifikan terhadap kemampuan berpikir kritis peserta didik yang dapat dilihat dari nilai p-value $0.000<0,05$ dan interval kepercayaan berada pada rentang 0,5040,668 .

Effect size pembelajaran Problem Based Learning (PBL) pada mata pelajaran Fisika terhadap kemampuan pemahaman konsep diperoleh $r^{2}=$ 0,124 (efek sedang), sehingga dapat disimpulkan bahwa model Problem Based Learning (PBL) memiliki pengaruh yang signifikan terhadap kemampuan pemahaman konsep peserta didik yang dapat dilihat dari nilai p-value $0.000<0,05$ dan interval kepercayaan berada pada rentang $0,504-0,668$.

Effect size pembelajaran Problem Based Learning (PBL) pada mata pelajaran Fisika terhadap kemampuan pemecahan masalah diperoleh $\mathrm{r}^{2}=$ 0,172 (efek sedang), sehingga dapat disimpulkan bahwa model Problem Based Learning (PBL) memiliki pengaruh yang signifikan terhadap 
kemampuan pemecahan masalah peserta didik yang dapat dilihat dari nilai $p$-value $0.000<0,05$ dan interval kepercayaan berada pada rentang 0,284-0.531.

Effect size pembelajaran Problem Based Learning (PBL) pada mata pelajaran Fisika terhadap kemampuan berpikir kreatif diperoleh $\mathrm{r}^{2}=0,575$ (efek besar), sehingga dapat disimpulkan bahwa model Problem Based Learning (PBL) memiliki pengaruh yang signifikan terhadap kemampuan berpikir kreatif peserta didik yang dapat dilihat dari nilai $p$-value $0.000<0,05$ dan interval kepercayaan berada pada rentang 0,674-0,823.

Effect size pembelajaran Problem Based Learning (PBL) pada mata pela jaran Fisika terhadap literasi sains diperoleh $r^{2}=0,477$ (efek besar), sehingga dapat disimpulkan bahwa model Problem Based Learning (PBL) memiliki pengaruh yang signifikan terhadap literasi sains peserta didik yang dapat dilihat dari nilai $p$-value $0.000<0,05$ dan interval kepercayaan berada pada rentang $0,56-0,788$

Effect size pembelajaran Problem Based Learning (PBL) pada mata pelajaran Fisika terhadap prestasi belajar diperoleh $\mathrm{r}^{2}=0,552$ (efek besar), sehingga dapat disimpulkan bahwa model Problem Based Learning (PBL) memiliki pengaruh yang signifikan terhadap prestasi belajar peserta didik yang dapat dilihat dari nilai $p$-value $0.000<0,05$ dan interval kepercayaan berada pada rentang $0,63-0,825$

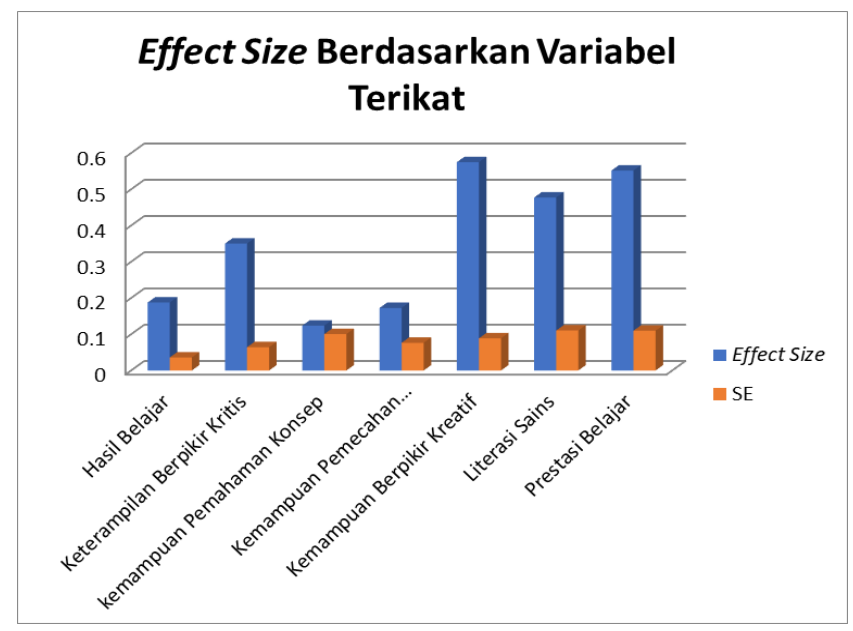

Gambar 2. Effect Size berdasarkan Variabel

Terikat
Bedasarkan gambar 2 menunjukkan bahwa ratarata effect size pada variabel sangat bervariasi. Model pembelajaran Problem based learning (PBL) memiliki effect size pada kemampuan berpikir kritis, kemampuan berpikir kreatif, literasi sains dan prestasi belajar berada pada kategori besar, sedangkan hasil belajar,kemampuan pemahaman konsep dan kemampuan pemecahan masalah berada pada kategori sedang.

\section{Pengaruh Model Pembelajaran Problem Based Learning (PBL) terhadap Pembelajaran Fisika berdasarkan Materi Pelajaran}

Data hasil analisis besar pengaruh (Effect Size) berdasarkan materi atau pokok bahasan dalam fisika disajikan dalam Tabel Berikut:

Tabel 5. Effect Size berdasarkan Materi

\begin{tabular}{|c|c|c|c|c|c|c|}
\hline Materi & $\mathbf{N}$ & $\mathbf{R}$ & $\mathbf{r}^{2}$ & SE & LLr & ULr \\
\hline Fluida & & & & & & \\
\hline $\begin{array}{l}\text { Statis } \\
\text { Suhu dan }\end{array}$ & 4 & 0.457 & 0.209 & 0.076 & 0.333 & 0.566 \\
\hline $\begin{array}{l}\text { Kalor } \\
\text { Hukum }\end{array}$ & 4 & 0.39 & 0.152 & 0.071 & 0.265 & 0.501 \\
\hline $\begin{array}{l}\text { Newton } \\
\text { Listrik }\end{array}$ & 4 & 0.642 & 0.412 & 0.071 & 0.554 & 0.716 \\
\hline Dinamis & 3 & 0.365 & 0.133 & 0.07 & 0.24 & 0.478 \\
\hline $\begin{array}{l}\text { Cahaya } \\
\text { dan Optik }\end{array}$ & 3 & 0.763 & 0.582 & 0.086 & 0.683 & 0.824 \\
\hline
\end{tabular}

Dari data yang terangkum pada Tabel 5 dapat dilihat bahwa effect size pembelajaran Problem Based Learning (PBL) pada mata pelajaran Fisika pokok bahasan Fluida Statis diperoleh $r^{2}=0,209$ (efek sedang), sehingga dapat disimpulkan bahwa model Problem Based Learning (PBL) memiliki pengaruh yang signifikan terhadap pembelajaran fisika pada pokok bahasan Fluida Statis yang dapat dilihat dari nilai $p$-value $0.000<0,05$ dan interval kepercayaan berada pada rentang 0,333 0,566 .

Effect size pembelajaran Problem Based Learning (PBL) pada mata pelajaran Fisika pokok bahasan Suhu dan Kalor diperoleh $\mathrm{r}^{2}=0,152$ (efek sedang), sehingga dapat disimpulkan bahwa model Problem Based Learning (PBL) memiliki 
pengaruh yang signifikan terhadap pembelajaran fisika pada pokok bahasan Suhu dan Kalor yang dapat dilihat dari nilai $p$-value $0.000<0,05$ dan interval kepercayaan berada pada rentang 0,265 0,501 .

\section{Effect size pembelajaran Problem Based Learning} (PBL) pada mata pelajaran Fisika pokok bahasan Hukum Newton diperoleh $r^{2}=0,412$ (efek besar), sehingga dapat disimpulkan bahwa model Problem Based Learning (PBL) memiliki pengaruh yang signifikan terhadap pembelajaran fisika pada pokok bahasan Hukum Newton yang dapat dilihat dari nilai $p$-value $0.000<0,05$ dan interval kepercayaan berada pada rentang $0,554-$ 0,716 .

\section{Effect size pembelajaran Problem Based Learning} (PBL) pada mata pelajaran Fisika pokok bahasan Listrik Dinamis diperoleh $\mathrm{r}^{2}=0,133$ (efek sedang), sehingga dapat disimpulkan bahwa model Problem Based Learning (PBL) memiliki pengaruh yang signifikan terhadap pembelajaran fisika pada pokok bahasan Listrik Dinamis yang dapat dilihat dari nilai $p$-value $0.000<0,05$ dan interval kepercayaan berada pada rentang 0,240,478 .

Effect size pembelajaran Problem Based Learning (PBL) pada mata pelajaran Fisika pokok bahasan Cahaya Dan Optik diperoleh $\mathrm{r}^{2}=0,0,582$ (efek besar), sehingga dapat disimpulkan bahwa model Problem Based Learning (PBL) memiliki pengaruh yang signifikan terhadap pembelajaran fisika pada pokok bahasan Cahaya Dan Optik yang dapat dilihat dari nilai p-value $0.000<0,05$ dan interval kepercayaan berada pada rentang $0,683-0,824$.

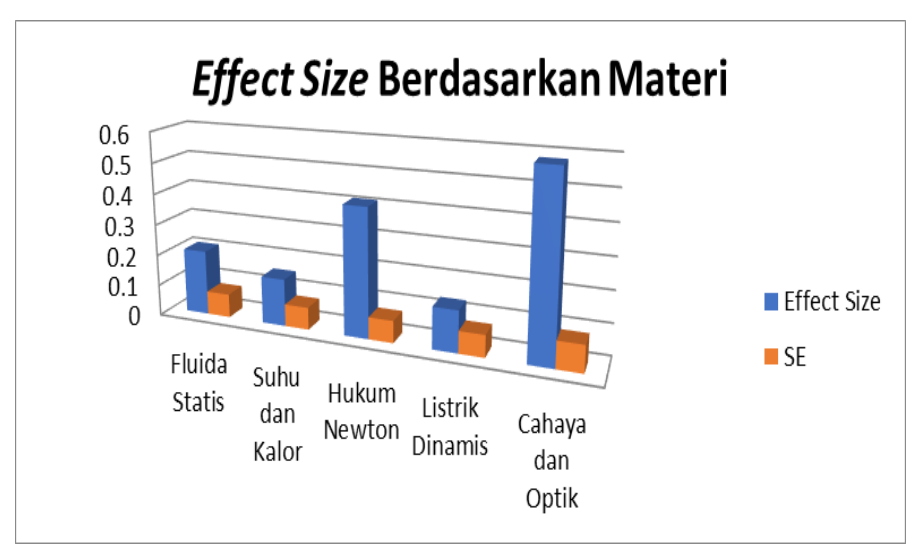

Gambar 3. Effect Size berdasarkan Materi

Bedasarkan gambar 4.2 menunjukkan bahwa ratarata effect size pada variabel sangat bervariasi. Model pembelajaran Problem Based Learning (PBL) memiliki effect size pada Hukum Newton dan Cahaya Dan Optik berada pada kategori besar, sedangkan Fluida Statis, Suhu dan Kalor, dan Listrik Dinamis berada pada kategori sedang.

\section{KESIMPULAN}

Besar pengaruh model Problem Based Learning (PBL) pada pembelajaran Fisika berdasarkan jenjang pendidikan mampu meningkatkan hasil belajar peserta didik baik tingkat SLTP maupun SLTA. Effect size yang diperoleh untuk jenjang SLTP sebesar 0,355 (kategori besar) dan SLTA sebesar 0,244 (kategori sedang). Besar pengaruh model Problem Based Learning (PBL) pada pembelajaran Fisika berdasarkan variabel terikat memiliki effect size pada kemampuan berpikir kritis, kemampuan berpikir kreatif, literasi sains dan prestasi belajar berada pada kategori besar, sedangkan hasil belajar,kemampuan pemahaman konsep dan kemampuan pemecahan masalah berada pada kategori sedang. Sedangkan besar pengaruh model Problem Based Learning (PBL) pada pembelajaran Fisika berdasarkan materi atau pokok bahasan memiliki effect size pada materi Hukum Newton dan Cahaya Dan Optik berada pada kategori besar, sedangkan Fluida Statis, Suhu dan Kalor, dan Listrik Dinamis berada pada kategori sedang.

\section{DAFTAR PUSTAKA}

Ariani, T., \& Suanti, W., 2016, Efektivitas Penggunaan Model Pembelajaran Problem Based Learning (PBL) Pada Pembelajaran Fisika Siswa Kelas VIII SMP Negeri 2 Lubuklinggau Tahun Pelajaran 2015/2016, Jurnal Inovasi dan Pembelajaran Fisika, 3(2), 1-6. https://doi.org/10.36706/jipf.v3i2.3846.

Demirel, M., \& Dağyar, M., 2016, Effects of Problem-Based Learning on Attitude: A Meta-analysis Study, EURASIA Journal of Mathematics, Science and Technology Education, 12(8), 2115-2137. 
https://doi.org/10.12973/eurasia.2016.1293 a.

Deswita, M., 2018, Pengaruh Penerapan Model Think Pair Share Dalam Pembelajaran Problem Based Learning Terhadap Hasil Belajar IPA Fisika Siswa Kelas VIII SMP. Jurnal Riset Fisika Edukasi dan Sains, $5(1)$, $25-32$. https://doi.org/10.22202/jrfes.2018.v5i1.27 71.

Ginaya, G., Kanca, I. N., \& Sri Astuti, N. N., 2020, Designing Problem-Based Learning (PBL) Model for Tourism Vocational Education in 4.0 Industry, International Journal of Linguistics, Literature and Culture, 6(1), 14-23. https://doi.org/10.21744/ijllc.v6n1.808.

Hidayah, S. N., Pujani, N. M., \& Sujanem, R., 2018, Implementasi Model Problem Based Learning untuk Meningkatkan Aktivitas Belajar dan Kemampuan Pemecahan Masalah Fisika Siswa Kelas X MIPA 2 MAN Buleleng Tahun Pelajaran 2017/2018, Jurnal Pendidikan Fisika Undiksha, 8(1), 1-11. http://dx.doi.org/10.23887/jjpf.v8i1.20575.

Jiniarti, B. E., Sahidu, H., \& Verawati, N. N. S. P., 2017, Implementasi Model Problem Based Learning Berbantuan Alat Peraga untuk Meningkatkan Aktivitas dan Hasil Belajar Fisika Siswa Kelas VIII SMPN 22 Mataram Tahun Pelajaran 2014/2015, Jurnal Pendidikan Fisika dan Teknologi, 1(3), 185-192. https://doi.org/10.29303/jpft.v1i3.257.

Kadir, 2015, STATISTIKA TERAPAN: Konsep, Contoh, dan Analsis Data dengan Program SPSS/Lisrel dalam Penelitian, PT Raja Grafindo Persada, Jakarta.

Kadir, K., 2017, META-ANALYSIS OF THE EFFECT OF LEARNING INTERVENTION TOWARD MATHEMATICAL THINKING ON RESEARCH AND PUBLICATION OF STUDENT, TARBIYA: Journal of Education in Muslim Society, 4(2), 162-
175.

https://doi.org/10.15408/tjems.v4i2.8010.

Manalu, A., 2016, Efek Model Problem Based Learning Terhadap Kemampuan Pemecahan Masalah Siswasma Negeri 2 Pematangsiantar, INPAFI (Inovasi Pembelajaran Fisika), 4(2), 1-8. https://doi.org/10.24114/inpafi.v4i2.5503.

Phasa, K. C., 2020, Meta Analisis Pengaruh Model Pembelajaran Problem Based Learning Terhadap Kemampuan Berpikir Kritis Dalam Pembelajaran Matematika, Jurnal Cendekia: Jurnal Pendidikan Matematika, 4(2), 711-723. https://doi.org/10.31004/cendekia.v4i2.296.

Pratiwi, I., 2019, EFEK PROGRAM PISA TERHADAP KURIKULUM DI INDONESIA, Jurnal Pendidikan dan Kebudayaan, 4(1), 51. https://doi.org/10.24832/jpnk.v4i1.1157.

Rahmat, S. A., Pasaribu, M., \& Darmadi, I. W., 2016, Pengaruh Pembelajaran Berbasis Masalah Terhadap Keterampilan Berpikir Kritis Siswa Pada Materi Gerak di Kelas X SMA Negeri 6 Sigi, JPFT (Jurnal Pendidikan Fisika Tadulako Online), 4(3), 16-21.

https://doi.org/10.22487/j25805924.2016.v 4.i3.6213.

Retnawati, H., Apino, E., Kartianom, K., Djidu, H., \& Anazifa, R. D., 2018, Pengantar Analisis Meta (Edisi 1), Parama Publishing, Yogyakarta. 